\title{
Effects of Increased Protein Intake as a Variant of Rural Diet in Human Volunteers of Rural Bengal
}

\author{
Sutapa Mukherjee ${ }^{1}$, Baishakhi Dey ${ }^{1}$, Subhayan Das ${ }^{1}$, Goutam Thakur ${ }^{2}$, \\ Chandan Chakraborty ${ }^{1}$ andAnalava Mitra ${ }^{1}$ \\ ${ }^{1}$ School of Medical Science and Technology, IIT Kharaghpur, India \\ ${ }^{2}$ Associate Professor, Dept. of Biomedical Engineering, Manipal Institute of Technology, \\ Manipal University, India
}

Received date: 17 September 2013; Accepted date: 26 November 2013; Published date: 3 December 2015

Academic Editor: Kaushik S. Bose

Correspondence should be addressed to: AnalavaMitra; analavamitra@gmail.com

Copyright (C) 2015. Sutapa Mukherjee, BaishakhiDey, Subhayan Das, Goutam Thakur, ChandanChakraborty and AnalavaMitra. Distributed under Creative Commons CC-BY 4.0

\begin{abstract}
Constant escalations in the number of diabetics' worldwide, associated complications and financial implications, failure of conventional therapy regimen to restore normoglycemia has brought to limelight the non-pharmacologic means like lifestyle and dietary interventions as one of the effective aids to combat type 2 diabetes. Economy, education, preference plays a role in dietary selection. Prolonged intake of carbohydrate enriched diet was found to be a causative of diabetes amongst poor rural Indian population of Bengal. Contrastingly, current research of three years RCT amongst rural Bengalis have shown that a daily increase in protein intake by $25-30 \%$ when compared with standard rural diet comprising of about $70 \%$ to $80 \%$ of carbohydrate, $10 \%$ fats and $10 \%$ protein, improved insulin sensitivity and lowered fasting blood glucose level amongst experimental population significantly $(\mathrm{p}=0.04)$ rather than the control group. Fasting serum insulin value decreased from $47 \pm 2.2 \mathrm{pmol} / 1$ to $44 \pm 2.4 \mathrm{pmol} / \mathrm{l}(\mathrm{p}=0.04)$ in the study group but amongst controls an increment from $42 \pm 2.4 \mathrm{pmol} / \mathrm{l}$ to $43 \pm 2.4 \mathrm{pmol} / \mathrm{l}$ was observed. Fasting Blood Sugar level amongst controls was initially $103 \pm 4 \mathrm{mg} / \mathrm{dl}$ and became $105 \pm 6 \mathrm{mg} / \mathrm{dl}$ but in the experimental group initial value of $109 \pm 12 \mathrm{mg} / \mathrm{dl}$ diminished to $103 \pm 8 \mathrm{mg} / \mathrm{dl}(\mathrm{p}=0.04)$ at the end of 3 years follow up. However blood lipid parameters (TC, LDL, HDL, and VLDL) were not significantly influenced by higher daily protein intake both in control and experimental group. Thus a conclusive fact found from the trial is that protein enriched, low carbohydrate diet can offer a positive impact on glycemic control kidney functions remaining normal. (250 words)
\end{abstract}

Keywords: dietary interventions; protein enriched; insulin sensitivity; glycemic control.

\section{Introduction}

Type 2 Diabetes Mellitus (DM) with its associates like insulin resistance, obesity, dyslipidaemia, accelerated changes of atherosclerosis and hypertension is one of the major health concerns in world as well as in Indian subcontinent with no exception. The

Cite this Article as: Sutapa Mukherjee, BaishakhiDey, Subhayan Das, Goutam Thakur, ChandanChakraborty and AnalavaMitra(2015), "Effects of Increased Protein Intake as a Variant of Rural Diet in Human Volunteers of Rural Bengal," JMED Research, Vol. 2015 (2015), Article ID 374069, DOI: 10.5171/2015.374069 
prevalence of the disease is increasing worldwide irrespective of age-groups, geographical locations, sex, occupations, economic status and various other factors and it is estimated to increase from $2.8 \%$ (2000) to $4.4 \%$ in 2030 as mentioned by King et al (1998). Research works of Enase et al (1992); Lindsay and Bennett (2001); Mitra and Bhattacharya (2008) stated factors responsible for this increased prevalence are many, arising from both nature (thrifty gene) and nurture. Enase et al (1992); Mitra and Bhattacharya (2008) and the Census of India2011 discussed on the varied factors of increased prevalence of diabetes in India like changes in the socio-cultural dimensions of the Indian society from traditional to modernization, increase in urbanization, successful implementation of panchayati raj (local semi-autonomous body of governance), increase in agrarian income with technological developments, changed life styles of a rural Indian, inappropriate diet and sedentary habits.

The rural populace of India is largely dependent on agriculture as depicted by the Census of India2011. The low income group suffered most due to inadequate health infrastructure facilities. Despite modernization, the socio-economic, cultural and ethnic believes of a rural Indian restrict wider acceptance of Western classical medicines and thus overlay the importance of traditional medicines in the form of herbal remedies, folklore medicines and nutraceuticals as evidenced by the researches of Mitra and Bhattacharya (2005) and Thakur et al (2009). Researches of Mitra et al (2007a) and Mukherjee et al (2009) have shown that a study based on long term carbohydrate enriched diet in rural Bengal is a cause of diabetes in the long run. Consequently, researchers studied the role of protein, in the aetiopathogenesis of the disease. Works of Luscombe et al (2002)showed that increased protein content in the diet not only reduced diabetic prevalence but was also easier to comply and was more satiating.

American Diabetes Association (ADA) recommended that a typical day's meals and snacks would provide $=1,500-2,000$ calories

with $* 50 \%$ of the calories from carbohydrate, $\approx 20 \%$ fromprotein, and $-30 \%$ from fat (ADA
2003). There was no evidence to indicate that the average daily protein intake should be modified if renal function was normal. Average income of an Indian in the rural areas is low and their main food item is carbohydrate. The populace is mainly lactovegetarian and protein is consumed mostly through milk, fish and vegetables as per Mitra et al (2007b). Studies of Mitra et al (2005, 2007a and 2007b), Luscombe et al (2002), ADA (2003), Mitra and Bhattacharya, (2006) on small number of volunteers in a selected rural Bengali population with normal life styles showed that a diet containing $20-30 \%$ of protein, $20-30 \%$ of fats and $50-70 \%$ of carbohydrates would reduce the Type 2 diabetes prevalence.

All these findings motivate us to conduct a study in human volunteers of our local region in rural Bengal for duration of three years with a daily protein intake of $25 \%$ to $30 \%$. The results were compared with standard rural diet comprising of about $70 \%$ to $80 \%$ of carbohydrate, $10 \%$ fats and $10 \%$ protein. Here, the researchers report the effects of increase in protein intake in the diet of the rural populace and its relationship with blood bio-chemistry (BBP) parameters, notably, fasting blood sugar (FBS), serum insulin, total cholesterol (TC), high density lipoprotein cholesterol (HDL), low density lipoprotein cholesterol (LDL), very low density lipoprotein cholesterol (VLDL) and serum triglycerides (TG) in 12 hours fasting conditions.

\section{Materials and Methods}

\section{Ethical Process}

The institute ethical committee was approached. The study protocol was explained to the volunteers in vernacular and written consents were obtained from them. The study was conducted as per ethical guidelines of biomedical research on human participants given by Indian Council of Medical Research (ICMR; New Delhi) 2006 (http://www.icmr.nic.in/ethical_guidelines.p df).

\section{Study Design}

The study was conducted amongst rural Bengali population to see the effects of increase amount of protein in the diet and 
corresponding changes in Blood Biochemistry Parameters (BBP) after 12 hours of fasting. The volunteers selected for the study were strictly monitored for three years. They were divided into two groups- control and experimental. In the control group the volunteers consumed about $10 \%$ protein, $70 \%$ to $80 \%$ of carbohydrate and $10 \%$ fats while in the experimental group the volunteers consumed about $25 \%$ to $30 \%$ protein. Utmost care was taken to avoid significant differences in any of the other dependent variables prior to the application of the control or treatment modes. All sections of people were considered for the study and much emphasis was on the socio-economic conditions. Based on commonality and questionnaire response, seven different patterns of diet (Table 1) were framed for both the groups to achieve the maximum compliance. Each pattern was previously analyzed for proximate compositions and the data thus obtained was recorded for reference. The local agents (LAs) appointed for the study instructed the volunteers about the process of intake, pre-processing and processing, storage and consumption and followed the identical patterns. LAs were entrusted to take any needful step on necessity in consultation with the research team in case of any deviations in food intake patterns such as social gatherings, etc. Steps were taken by the research team to analyze the proximate composition of the food items as provided by Rangana, (1986); record any deviations and to formulate the daily meals. Deviations from the usual pattern occurred four times per volunteer in the experimental group and thrice in the control group. The LAs collected and labeled the different daily food items of a specific volunteer for analysis of the proximate composition by the research team.

Table 1: Experimental Design of Seven Different Daily Food Intake Patterns

\begin{tabular}{|c|c|c|}
\hline Pattern & Control Group & Experimental Group \\
\hline 1 & Rice 400g & Rice $400 \mathrm{~g}+$ Potato $100 \mathrm{~g}+$ Pulse $50 \mathrm{~g}+$ Fish $50 \mathrm{~g}$ \\
\hline 2 & Rice 400g + Pulse $50 \mathrm{~g}$ & $\begin{array}{l}\text { Rice } 400 \mathrm{~g}+\text { Pulse } 50 \mathrm{~g}+\text { Vegetables } 100 \mathrm{~g} \\
\text { + Milk } 500 \mathrm{ml}\end{array}$ \\
\hline 3 & Rice 400g + Vegetables 50g & Rice $400 \mathrm{~g}+$ Milk 1lit + Potato $100 \mathrm{~g}$ \\
\hline 4 & Rice $400 \mathrm{~g}+$ Potato $100 \mathrm{~g}$ & $\begin{array}{l}\text { Rice } 400 \mathrm{~g}+\text { Fish } 50 \mathrm{~g}+\text { Milk } 500 \mathrm{ml} \\
\text { Vegetables } 100 \mathrm{~g}+\text { Potato } 50 \mathrm{~g}\end{array}$ \\
\hline 5 & $\begin{array}{l}\text { Rice } 400 \mathrm{~g}+\text { Green leafy } \\
\text { vegetables } 100 \mathrm{~g}\end{array}$ & $\begin{array}{l}\text { Rice } 400 \mathrm{~g}+\text { Pulse } 100 \mathrm{~g}+\text { Fish } 50 \mathrm{~g}+ \\
\text { Potato } 100 \mathrm{~g}+\text { Vegetables } 100 \mathrm{~g}\end{array}$ \\
\hline 6 & $\begin{array}{l}\text { Rice } 400 \mathrm{~g}+\text { Other Tubers } \\
\text { (excluding Potato) } 100 \mathrm{~g}\end{array}$ & $\begin{array}{l}\text { Rice } 400 \mathrm{~g}+\text { Pulse } 100 \mathrm{~g}+\text { Green leafy } \\
\text { Vegetables } 100 \mathrm{~g}+\text { Vegetables } 100 \mathrm{~g}+ \\
\text { Fish } 50 \mathrm{~g}+\text { Milk } 500 \mathrm{ml}\end{array}$ \\
\hline 7 & $\begin{array}{l}\text { Green leafy vegetables } 200 \mathrm{~g} \\
+ \text { Tubers } 100 \mathrm{~g} \text { (excluding potato) } \\
\text { + Various types of aquatic } \\
\text { vegetations }\end{array}$ & $\begin{array}{l}\text { Rice } 400 \mathrm{~g}+\text { Egg } 1+\text { Green leafy vegetables } \\
100 \mathrm{~g}+\text { Vegetables } 100 \mathrm{~g}+\text { Fish } 50 \mathrm{~g}\end{array}$ \\
\hline
\end{tabular}

Deviations in the normal exercise patterns in respect to volunteers in each group were reported and modifications in the dietary prescriptions were made accordingly as per standard charts. Such occurrences occurred twelve times per volunteer in the experimental group and nine times in the control group.

Blood samples were collected under aseptic conditions before the initiation of the study and then at a yearly interval by skilled professionals (not made aware of the study), 
labeled and immediately sent for bio-chemical analysis.

\section{Selection of Volunteers}

Initially based on location advantage and permission by village level authorities, three villages; Balarampur, Gopali and Salua of Kharagpur 1 Block (India), were fixed for the study. Of the populace in these villages, initially 420 adult healthy adult volunteers (35-55 years of age) of either sex were selected as per initial data screening at local level viz., economic conditions, literacy level, willingness of the volunteer, adherence to the study protocol, earlier medical records, personal and family history, availability to participate in the weekly meetings, etc. The willingness of the local panchayets(local autonomous elected constitutional body) to get actively involved was also being considered in the process. Of the 420 volunteers thus initially screened, 54 refused to give written consents. 100 volunteers demanded money for their participation and were eliminated and 26 people went to other places for various reasons and their data were omitted for consideration. Of the remaining 240 volunteers, 200 volunteers were selected on random selection basis (lottery) due to economic reasons. During the study, 80 failed to adhere to the prescribed dietary regimens and their data was not taken into account. Finally, 120 volunteers, 60 for each group (experimental and control) were selected for the study (Figure 1).

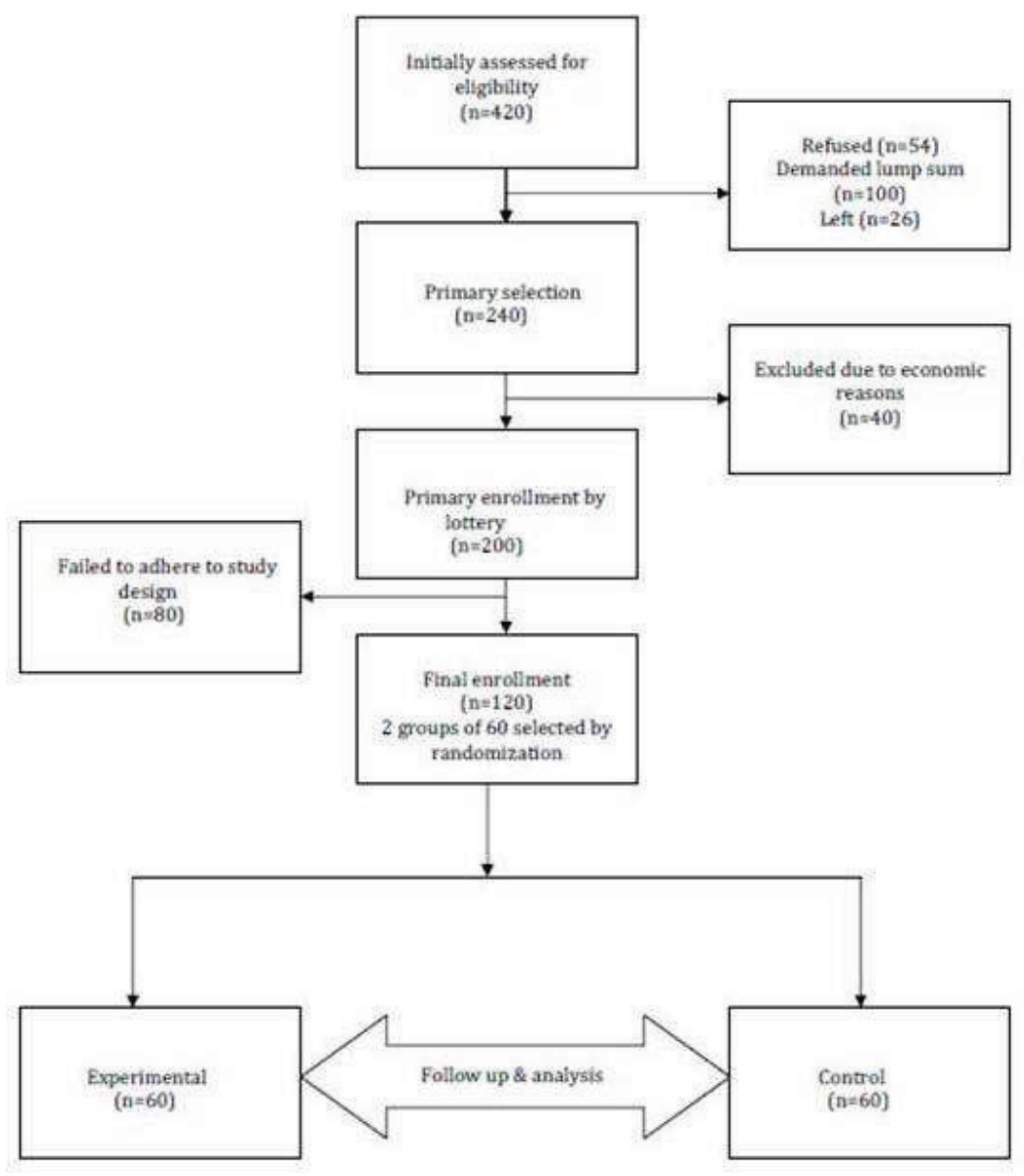

Figure 1: Flow Chart Showing Selection of Volunteers 


\section{Selection of Local Agents}

LAs were screened by the research team from the local villagers in consultation with the respective panchayets.Twelve LAs residing in 4 villages ( 3 in each village) in close proximity with IIT Kharagpur were selected for the purpose. LAs, under instruction of the research team, supervised the preparations of the daily foods which were done in Indianstyle kitchens under hygienic conditions and these were taken by the subjects. The local agents by continuous interaction with the volunteers tried to reduce the deviations in the dietary patterns and modified the diet in consultation with research team when there were deviations due to social gatherings, exercise patterns etc. For the control group (mostly vegans in nature), the foods were made in a similar manner and consist mainly of cereals. LAs were also responsible for the daily monitoring of the subjects' health and compliance. For assessing these two subjective parameters emphasis were led on to interview and response to research team.LAs also monitored the exercise patterns of the volunteers closely. Any deviations from the daily exercise pattern of the volunteers were recorded and approximate changes in daily energy expenditure due to such activities were obtained from standard charts available by the research team. Accordingly calculations in the dietary intake patterns were modified. LAs in consultation with the respective panchayets arranged weekly meetings where village health workers, members of the research team, and other participants discussed about various activities concerned with the study protocol, health awareness projects and various other prevailing socio-cultural and economic schemes.

\section{Analysis of Food Items}

Rural Indian diet is mainly lacto-vegetarian and vegans consume protein of vegetable origin only studied by Mitra et al (2009). For the dietary survey, the process laid down by researchers like Rao and Gopalan $(1971,1977)$ were followed. The daily diet was closely monitored, collected, labeled, homogenized and was sent to food analysis laboratory of IIT Kharagpur. As the food intake depends on various factors like its mode of consumption-taking raw or cooked, pre-processing (removal of impurities like mud, clay, herbicides, pesticides etc through washing, soaking and cleaning) cooking techniques, storage, pre-heating of stored food before consumption etc. the proximate compositions may vary as evidenced by Mitra and Bhattacharya, (2005). For that reason, the daily food items to be consumed by the selective volunteer are collected separately as one unit of the family under hygienic conditions, appropriately labeled, homogenized, and analyzed in the Food and Analysis Laboratory at IIT Kharagpur as per the methods described in Rangana (1986) for proximate compositions like protein, fats, carbohydrates and fibers.

\section{Collection of Blood Samples}

12 hours fasting values were taken for initial readings and then also at yearly intervals for yearly readings (three years duration) in the month of September as per the procedures laid by Mitra et al (2007b). Measurement of BBP like, Total Cholesterol (TC), High Density Lipoprotein (HDL), Low Density Lipoprotein (LDL), Very Low Density Lipoprotein (VLDL), Triglycerides (TG) and Fasting Blood Sugar (FBS) were performed by standard methods as depicted by Boehringer Mannheim (Instruction sheets for manual assays $\mathrm{GmbH}$ diagnostica, Catalogue no. 400 971, catalogue no.543 004, catalogue no.124 095, Catalogue no 124 966, Catalogue no.263 826, catalogue no. 123 919). Serum insulin level was measured in a private laboratory at Midnapore.

\section{Equipments Used}

Blood samples were tested for FBS, TC, and HDL by using Photometer 4010 (Boehringer, Manheim, Manheim, Germany). VLDL was computed as $1 / 5$ th of TG value and LDL was computed by the difference TC - (VLDL + HDL) (Boehringer Mannheim Catalogue no. 400 971, catalogue no.543 004, catalogue no.124 095, Catalogue no 124 966, Catalogue no.263 826, catalogue no. 123 919). Serum insulin concentrations were determined by ELISA at a private laboratory at Midnapore using an automated EIA Analyzer (Bio-Rad, Hercules, CA, USA). 


\section{Statistical Analysis}

To see the effects of protein in rural diet, the initial values obtained from the volunteers are taken as reference and statistical tests were performed to investigate whether increased intake of protein in diet has any long term effect on the blood gluco-lipid profile (FBS, TC, HDL, VLDL, LDL, TG) and serum insulin values.

In order to perform independent $t$-test, we assumed $\mu_{0}$ and $\mu$ as the average values of each BBP eg. FBS, TC, HDL, VLDL, LDL, TG and serum insulin level for the control and experimental group respectively. The objective here was to determine whether $\mu$ is less than $\mu_{0}$ or not, i.e., to formulate a onetailed test as follows

$$
H_{0}: \mu=\mu_{0} \text { versus } H_{1}: \mu<\mu_{0} .
$$

Let $\mathrm{X}_{0} \mathrm{be}$ the sample mean of the control group and Xbe that of the experimental group. In order to test $\left(H_{0}, H_{1}\right)$, our test statistic under $H_{0}$ is

$$
t=\frac{\bar{X}-\bar{X}_{0}}{s \sqrt{2 / n}}
$$

Where $\quad S=\sqrt{\frac{s_{1}^{2}+S_{2}^{2}}{2}}$

$\mathrm{s}_{1}{ }^{2}$ and $\mathrm{s}_{2}{ }^{2}$ being the sample variances of the control group and the experimental group respectively. Equation (1) has been simplified here from the standard one when the sample sizes $\mathrm{n}_{1}$ and $\mathrm{n}_{2}$ are equal. In our study, $\mathrm{n}_{1}=60$. It is to be noted that the sample size being very large, the above $t$-test statistics can be well approximated by normal distribution and the p-value for different parameters to be calculated. The decision rule is to reject the null hypothesis $\left(H_{0}\right)$ if $t_{0}<-\frac{t \alpha}{2}, n-1$ at $\alpha \%$ level of significance and $(n-1)$ degrees of freedom, which is obtained from biometrica table provided by Elston and Johnson (2008). SPSS package is used here for data analysis and the level of significance was set to $\mathrm{p}<0.05$.

\section{Results}

Clinical, anthropometrical and biochemical evaluations of the volunteers before the study were as follows:

Age- $47.3 \pm 8.2$ years (Mean \pm SD)

Sex- Males 66, Females 54

Weight- $57.6 \pm 2.6 \mathrm{~kg}$

Body Mass Index (BMI) - 21.8 \pm 2.4

At the end of the study, it was found that the changes were observed in respect to volunteers' weight and BMI. Volunteers' weights and BMI were $57.3 \pm 2.8 \mathrm{~kg}, 21.7 \pm 2.5$ respectively resulted statistically insignificant changes. Clinical parameters were also evaluated at the end of the study. Systolic blood pressure was increased by $9 \pm 4 \mathrm{~mm}$ of $\mathrm{Hg}$; diastolic blood pressure was increased by $6 \pm 2 \mathrm{~mm}$ of $\mathrm{Hg}$ while mean pressure was increased by $5 \pm 2 \mathrm{~mm}$ of $\mathrm{Hg}$ in the experimental group. Statistically insignificant increase $(\mathrm{p}=0.06)$ in blood urea along with increase in hemoglobin (\%) were observed in the experimental group. All the other BBP remained unaltered.

Table 2 showed anthropometrical, clinical and biochemical evaluations of volunteers and the results were described in respect of $\mathrm{M}_{0}$ (i.e. at the start of the experiment) and $\mathrm{M}_{3}$ (i.e. at the end of the experiment) 
Table2: Anthropometrical, Biochemical and Clinical Data in Both Experimental and Control Groups of Human Volunteers, Parameters Were Summarized in Mean \pm SD, Values at the Start and End of the Experiment Were Denoted by $M_{0}$ And $M_{3}$ Respectively.

\begin{tabular}{|c|c|c|}
\hline Parameters & Experimental Group & Control Group \\
\hline $\begin{array}{l}\text { Age (years) } \\
\text { Sex }\end{array}$ & Sex & $46.2 \pm 5.1$ \\
\hline Male (n) & 33 & 27 \\
\hline Female (n) & 28 & 32 \\
\hline Weight (kg) & $\begin{array}{l}57.6 \pm 2.6\left(\mathrm{M}_{0}\right) \\
57.4 \pm 3.2\left(\mathrm{M}_{3}\right)\end{array}$ & $\begin{array}{l}57.1 \pm 2.8\left(\mathrm{M}_{0}\right) \\
57.3 \pm 2.4\left(\mathrm{M}_{3}\right)\end{array}$ \\
\hline BMI $\left(\mathrm{kg} / \mathrm{m}^{2}\right)$ & $\begin{array}{l}21.8 \pm 2.6\left(\mathrm{M}_{0}\right) \\
21.7 \pm 2.4\left(\mathrm{M}_{3}\right)\end{array}$ & $\begin{array}{l}21.3 \pm 1.7\left(\mathrm{M}_{0}\right) \\
21.3 \pm 2.4\left(\mathrm{M}_{3}\right)\end{array}$ \\
\hline \multirow[t]{2}{*}{ SBP (mm of Hg) } & $110 \pm 8\left(\mathrm{M}_{0}\right)$ & $118 \pm 6\left(\mathrm{M}_{0}\right)$ \\
\hline & $118 \pm 10\left(\mathrm{M}_{3}\right)$ & $116 \pm 4\left(\mathrm{M}_{3}\right)$ \\
\hline \multirow[t]{2}{*}{$\mathrm{DBP}(\mathrm{mm}$ of $\mathrm{Hg})$} & $76 \pm 8\left(M_{0}\right)$ & $78 \pm 10\left(\mathrm{M}_{0}\right)$ \\
\hline & $83 \pm 5\left(M_{3}\right)$ & $76 \pm 7\left(M_{3}\right)$ \\
\hline \multirow[t]{2}{*}{ Serum bilirubin (mg/dl) } & $0.6 \pm 0.3\left(\mathrm{M}_{0}\right)$ & $0.5 \pm 0.3\left(\mathrm{M}_{0}\right)$ \\
\hline & $0.7 \pm 0.2\left(\mathrm{M}_{3}\right)$ & $0.6 \pm 0.3\left(\mathrm{M}_{3}\right)$ \\
\hline \multirow[t]{2}{*}{ Hemoglobin (gm \%) } & $13.1 \pm 0.4\left(\mathrm{M}_{0}\right)$ & $14 \pm 0.4\left(\mathrm{M}_{0}\right)$ \\
\hline & $14.1 \pm 0.8\left(\mathrm{M}_{3}\right)$ & $14 \pm 0.6\left(\mathrm{M}_{3}\right)$ \\
\hline \multirow[t]{2}{*}{ Serum GPT(iu/l) } & $37 \pm 3.2\left(\mathrm{M}_{0}\right)$ & $32 \pm 5.3\left(\mathrm{M}_{0}\right)$ \\
\hline & $36 \pm 5.4\left(\mathrm{M}_{3}\right)$ & $34 \pm 4.6\left(\mathrm{M}_{3}\right)$ \\
\hline \multirow[t]{2}{*}{ Blood Urea (mg/dl) } & $22 \pm 3.2\left(\mathrm{M}_{0}\right)$ & $18 \pm 3.6\left(\mathrm{M}_{0}\right)$ \\
\hline & $23 \pm 3.8\left(\mathrm{M}_{3}\right)$ & $16 \pm 4.2\left(\mathrm{M}_{3}\right)$ \\
\hline \multirow[t]{2}{*}{ Serum creatinine $(\mathrm{mg} / \mathrm{dl})$} & $2.4 \pm 0.6\left(\mathrm{M}_{0}\right)$ & $2.2 \pm 0.6\left(\mathrm{M}_{0}\right)$ \\
\hline & $2.0 \pm 0.4\left(\mathrm{M}_{3}\right)$ & $2.6 \pm 0.4\left(\mathrm{M}_{3}\right)$ \\
\hline \multirow[t]{2}{*}{ Serum uric acid (mg/dl) } & $5.3 \pm 0.8\left(\mathrm{M}_{0}\right)$ & $4.3 \pm 1.2\left(\mathrm{M}_{0}\right)$ \\
\hline & $5.5 \pm 0.5\left(\mathrm{M}_{3}\right)$ & $4.7 \pm 0.8\left(\mathrm{M}_{3}\right)$ \\
\hline \multirow[t]{2}{*}{ Serum GOT(iu/l) } & $33 \pm 2.6\left(M_{0}\right)$ & $34 \pm 1.7\left(M_{0}\right)$ \\
\hline & $33 \pm 2.7\left(\mathrm{M}_{3}\right)$ & $34 \pm 1.5\left(\mathrm{M}_{3}\right)$ \\
\hline
\end{tabular}

aBMI, body mass index; SBP, DBP, systolic and diastolic blood pressure, respectively; GPT, glutamic pyruvic transaminase; GOT, glutamic oxaloacetic transaminase.

Figure 2 shows the changes in the BBP of interest, i.e., TC, HDL, LDL, TG and FBS. Analyzing the result, it is evident that the changes in TG, VLDL, HDL and LDL in both the groups were statistically insignificant. The changes in FBS showed that it was initially $103 \pm 4 \mathrm{mg} / \mathrm{dl}$ in the control group and at the end of study period of 3 years it became $105 \pm 6 \mathrm{mg} / \mathrm{dl}$ while in the experimental group FBS was initially $109 \pm 12 \mathrm{mg} / \mathrm{dl}$ and finally it was $103 \pm 8 \mathrm{mg} / \mathrm{dl}(\mathrm{p}=0.04)$. TG values in the control group was initially $125 \pm 10 \mathrm{mg} / \mathrm{dl}$ and at end it became $130 \pm 8 \mathrm{mg} / \mathrm{dl}$ and in the experimental group was initially $130 \pm 10$ $\mathrm{mg} / \mathrm{dl}$ and finally $134 \pm 9 \mathrm{mg} / \mathrm{dl}(\mathrm{p}=0.07)$. VLDL value in the control group at the beginning was $25 \pm 3 \mathrm{mg} / \mathrm{dl}$ and it ended to $26 \pm 2 \mathrm{mg} / \mathrm{dl}$. In the experimental group VLDLvalue was $26 \pm 4 \mathrm{mg} / \mathrm{dl}$ (beginning) and $27 \pm 2 \mathrm{mg} / \mathrm{dl}$ at the end $(\mathrm{p}=0.06)$. TC, HDL and LDL values showed no changes in both the groups during the experimentation. 


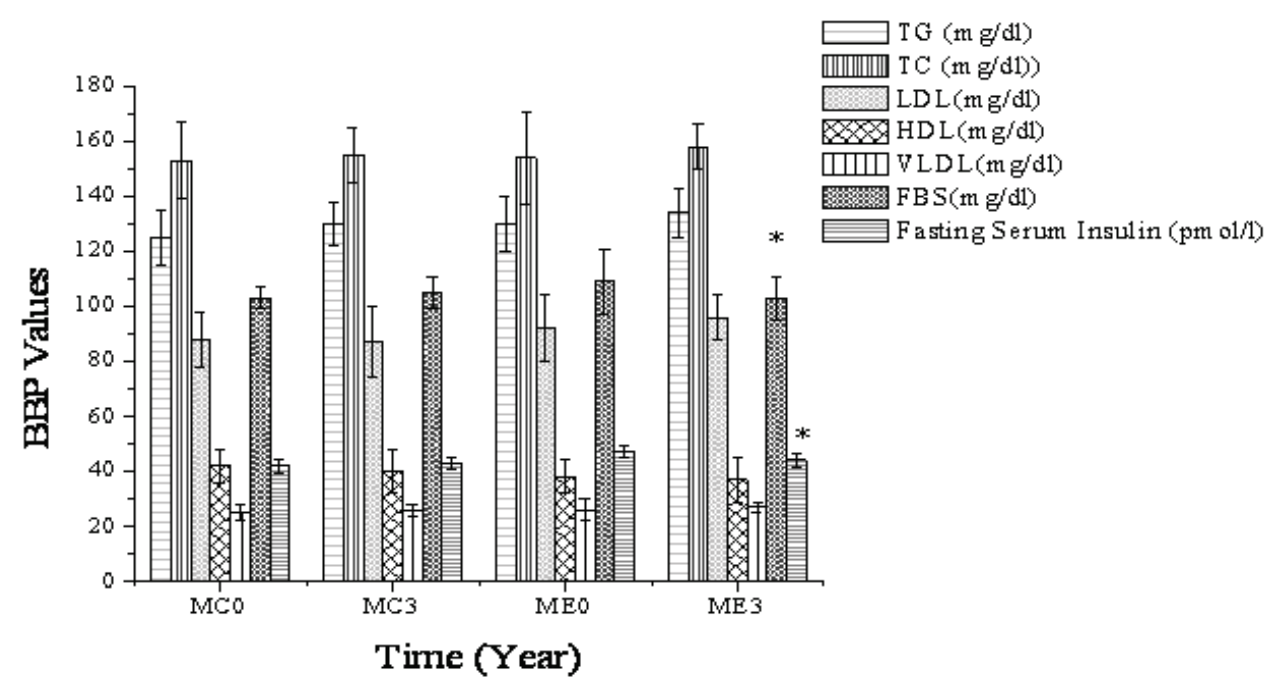

Figure 2:BBP of 60 Volunteers (Control And Experimental Groups) Who Were on a Normal Diet (Control) and after Receiving Prescribed Protein Rich Diet (Only Variable) for 3 Years (Experimental).

Years represented as M0 and M3. MCO and MC3, control group; ME0 and ME3, experimental group. The BBP pattern showed significant changes in FBS and fasting serum insulin level. Parameters summarized as mean \pm SD $(n=60) *$ Statistical significance $(<0.05)$.

Analyzing the changes in Fasting Serum Insulin values it was evident that in the control group the data showed an increase from $42 \pm 2.4 \mathrm{pmol} / \mathrm{l}$ to $43 \pm 2.4 \mathrm{pmol} / \mathrm{l}$ while in the experimental group fasting serum insulin value decreased from $47 \pm 2.2 \mathrm{pmol} / \mathrm{l}$ to $44 \pm 2.4$ $\mathrm{pmol} / \mathrm{l}(\mathrm{p}=0.04)$.

So, the study indicates an increase in protein content in rural diet significantly $(p=0.04)$ lowered fasting blood sugar level and fasting insulin respectively.

Age specific statistical data analysis in both experimental and control groups showed no significant variations and hence not taken into account and both the groups were described as a whole. Statistical analysis was done as per gender in each group and in totality. However, the records demonstrated no deviations on the basis of gender.

\section{Discussion}

A uniform dietary pattern, with minor variations (based on age, gender and physical activities) are followed by people with particular lifestyle patterns for an optimized homeostasis in energy regulation balance. Based on the lifestyle patterns, persons performing heavy activities need more energy and naturally they require more quantities of food to maintain their energy balance and regulation of appetite and satiety centers. So, food intake is independent of income and higher income group with less consumption of energy may consume less quantity of food. This is true in the traditional Indian society where a particular admix of food is preferred and followed. The similarity in diet in the urban sector in the non-diabetic and the newly diagnosed diabetic persons showed that the development of diabetes was probably not related to changes in dietary habits. Shobana et al (1998) observed that Body Mass Index (BMI), Waist-Hip ratio (WHR), plasma glucose, serum cholesterol and triglycerides were not significantly influenced by the total calorie consumption. On the contrary, researches of Ghafoarunissa (1996)reported that fat, protein, and calorie intake had a proportional relationship with income. Works of Luscombe et al (2001) have shown that in Type 2 diabetics, a low-fat diet with an increased protein-carbohydrate ratio does not significantly increase weight loss or blunted the fall in resting energy expenditure. Reports from Prevalence of diabetes in India study (PODIS) through survey of a large number of people from rural as well as urban population of India showed that prevalence of 
diabetes and impaired fasting glucose (IFG) is lower in rural population in comparison to urban population also evidenced by the works of Shobana et al (1998).

In India majority of population is vegetarian. So, balanced food and adequate dietary requirements are of prime concern to reduce the incidence of insulin resistance syndrome as stated by Rao et al (2002). Reduced fiber intake and increased consumption of animal fats and processed carbohydrates were the main changes in dietary habits in Westernized societies and likely to be accepted in Indian society at large due to impact of modernization and urbanization. $\mathrm{Hu}$ et al (2001) observed that both animal fats and carbohydrates have been associated with excessive predisposition to diabetes, mainly through development of obesity. Reduced fiber content in the diet leads to increased predisposition to diabetes. Higher daily energy intake, through consumption of saturated fats and refined carbohydrates, increases the chance of obesity and Type 2 diabetes. As estimated, for each $\mathrm{kg}$ of weight gain, risk for diabetes increases $\sim 4.5$ per cent observed by Mokdad et al (2001). In this view, a study conducted in two groups of Chinese, living in North America and main land of China, suggests that due to differences in nutrient intakes and physicalactivity,ChineseinChinaweighedlessan dwere leanerthanNorthAmericanChinese and also have lower rate of chronic diseases shown by Lee et al (1994).In the rural Indian set up usually there is nomajor change in the diet of a diabetic and other normal family members. Mani, (1998) observed that in urban set up, changes were brought in their life styles, eating habits along with the environmental changes and stress induced factors which conclude the distinguishable changes in the prevalence of the disease pattern.

Increased plasma amino acid availability in both animals and humans had been shown to cause enhanced translation initiation and protein synthesis and the inhibition of insulinstimulated glucose transport in skeletal muscle. Frédéric et al (2005) showed that dietary interventions in animal fed proteins from various sources resulted in drastically different outcomes in terms of glucose metabolism and insulin signaling in skeletal muscles. Others school of thought like Schneider et al (1996) believed that highprotein diet promoted the onset of diabetes, but it did not increase significantly the incidence of the disease. Considering the urbanized sector of India, a daily intake of 2,500 calories contributes about $100 \mathrm{~g}$ of protein which is about twice that is needed to replace daily protein loss. The excess ingested protein causes gluconeogenesis. Adding protein to carbohydrate in the diet does not slow the absorption or peak of the glucose response observed by Gannon and Nuttall (2004). Carbohydrate content of the meal was the main determinant of the peak glucose response. Layman et al (2009) mentioned the advantage of the high-protein, low-carbohydrate diet which almost eliminated carbohydrate and is lower in calories and so resulted in weight loss. Protein exerts a more positive effect on satiety per calorie than both carbohydrate and fat. However, foods rich in animal protein are often high in fat, especially saturated fats and cholesterol, and the long-term effects on lipids from these diets are unknown. The highprotein, low carbohydrate diets are often dramatic in terms of weight loss and impact on glycemia, but no long-term controlled clinical research has been done till date as stated by Layman et al (2009) and Franz, (2000).

\section{Conclusions}

The study based on rural population of India demonstrates that increase in protein intake lowers FBS and fasting insulin level. However, it needs financial flexibility from sponsors to perform further advancements with higher number of volunteers.

The study with increase in protein content in a rural population showed proteins in diet may have some effect in fasting blood sugar level and fasting insulin value. The results showed insulin sensitivity may be increased or resistance may be reduced. The study needs to be validated with stringent regulatory measures in a closed population with almost minimal changes in life style patterns and in a larger section of volunteers for a long term study. 


\section{Acknowledgements}

The authors are indebted to ArunavaMitra (Crompton Greaves Ltd, Mumbai, India), Ashok Nanda (Mathematics and Statistics Department, IIT Kharagpur, West Bengal, India), SatyahariDey (Biotechnology Department, IIT Kharagpur), AmitBasak (Chemistry Department, IIT Kharagpur), HN Mishra and TK Goswami (Agriculture and Food Engineering Department, IIT Kharagpur), non-governmental organisations (NGOs), the volunteers and their families, officials of Spandan Diagnostic (Midnapore, India) and Bidhan Chandra Roy Technology Hospital for their support.

\section{Declaration of Interest}

The authors have no conflict of interest.The authors alone are responsible for the content and writing of the paper.

\section{References}

1.Anonymous.American Diabetes Association (ADA) (2003). 'Evidence-Based Nutrition Principles and Recommendations for the Treatment and Prevention of Diabetes and Related Complications,' Diabetes Care , 26 7072.

2.Anonymous.Census of India.(2011). Office of registrar General and Census Commissioner, India.http://www.censusindia.gov.in/vital_sta tistics/SRS_Reports.html

3.Enase, A. Yusuf, S. \& Mehta J. L. (1992). "Prevalence of Coronary Artery Disease in Asian Indians," The American Journal of Cardiology, 70(9) 945-949.

4.Elston, R.C. \& Johnson, W.D. (2008).'Basic Biostatistics for Geneticists and Epidemiologists,' A John Wiley and Sons, Chichester, West Sussex, UK.

5.Franz, M.J. (2000). 'Protein Controversies in Diabetes,' Diabetes Spectrum, 13(3) 132-141.

6.Frédéric, T. Hélène, J. \& André, M. (2005). "Modulation of Insulin Action by Dietary Proteins and Amino Acids: Role of the Mammalian Target of Rapamycin Nutrient Sensing Pathway," Current Opinion in Clinical Nutrition and Metabolic Care, 8(4) 457-462.
7..Gannon, M.C. \&Nuttall, F.Q. (2004).“Effect of a High-Protein, Low-Carbohydrate Diet on Blood Glucose Control in People with Type 2 Diabetes," Diabetes 53(9) 2375-2382.

8..Ghafoarunissa (1996). "Fats in Indian Diets and Their Nutritional and Health Implications," Lipids 31 287-291.

9..Gopalan, C, Rama Sastri, B.V., Balasubramanian, S.C. (1977). 'Nutritive Value of Indian Foods,' National Institute of Nutrition. Indian Council of Medical Research. Hyderabad

10.Hu, F.B., van Dam, R.M. \& Liu, S (2001). "Diet and Risk of Type II Diabetes: The Role of Types of Fat and Carbohydrate," Diabetologia 44(7) 805-17.

11.King, H, Aubert, R.E. \& Herman, W.H. (1998). "Global Burden of Diabetes, 19952025-Prevalence, Numerical Estimates and Projections," Diabetes Care 21(9) 1414-1431.

12.Layman, D.K., Evans, E.M., Erickson, D., Seyle,R. J., Weber, J., Bagshaw, D., Griel, A., Psota, T. \&Etherton, P.K. (2009). "A ModerateProtein Diet Produces Sustained Weight Loss and Long-Term Changes in Body Composition and Blood Lipids in Obese Adults," The Journal of Nutrition, 139(3) 514-521.

13.Lee, M.M., Wu-Williams, A., Whittemore, A.S., Zheng, S., Gallagher, R., The, C., Zhou, L., Wang, X., Chen, K., Ling, C., Jiao, D., Jung, D. \&Paffenbarger, R.S. (1994). "Comparison of Dietary Habits, Physical Activity and Body Size among Chinese in North America and China," TheInternational Journal of Epidemiology, 23(5) 984-90.

14.Lindsay, R.S. \& Bennett, P.H. (2001). “Type 2 Diabetes, the Thrifty Phenotype - An Overview," British Medical Bulletin, 60(1) 2132.

15.Luscombe, N.D., Clifton, P.M., Noakes, M., Parker, B. \&Wittert, G. (2002). "Effects of Energy-Restricted Diets Containing Increased Protein on Weight Loss, Resting Energy Expenditure, and the Thermic Effect of Feeding in Type 2 Diabetes," Diabetes Care 25(4) 652-657.

16.Mani, U.V. (1998). "Rural Vs. Urban Differences in Diet and The Prevalence of Diabetes Mellitus in Western India," 
International Journal of Diabetes in Developing Countries 18 7-9.

17.Mitra, A. \& Bhattacharya, D. (2005).'Effects of Overall Consumption, Dietary Patterns, Cooking, on Patients Suffering from Non Insulin Dependent Diabetes Mellitus,' Journal of Interacademicia 9(4) 635-642.

18.Mitra, A., Basu, B. \& Mukherjee, S. (2009). 'Significance of Different Dietary Habits in Sections of Rural Indian Diabetics,' International Journal of Human Ecology 26(2) 89-98.

19.Mitra, A \& Bhattacharya, D (2006). 'Effects of Walking on Patients of Insulin Resistance,' Journal of Interacademicia 10(3) 373-380.

20.Mitra, A. \& Bhattacharya, D. (2008). "Effects of Melatonin in Mild diabetics with Dyslipidaemia," International Journal of Human Ecology 23(2) 109-114.

21.Mitra, A., Bhattacharya, D. \& Roy, S. (2007a). "Dietary Influence on TYPE 2 Diabetes (NIDDM)," International Journal of Human Ecology 21(2) 139-147.

22.Mitra, A, Bhattacharya, D. \& Roy, S (2007b). "Benefits of Fats in Diet on Health of Patients Suffering from Type 2 Diabetes (NIDDM)," International Journal of Human Ecology 21(3) 215-222.

23.Mokdad, A.H., Bowman, B.A., Ford, E.S., Vinicor, F., Marks, J.S. \&Koplan, J.P. (2001)."The Continuing Epidemics of Obesity and Diabetes in the United States," The Journal of the American Medical Association 286(10)
1195-200.

24.Mukherjee, S, Thakur, G, Kumar, B.D., Mitra, A, Chakraborty, C (2009). "Long Term Effects of Carbohydrate Rich Diet to Rural Bengali in Respect to Their Fasting Blood Sugar, Lipid Profile and Serum Insulin Values in Rural Bengalis," Journal of Diabetes 1(4) 288-295.

25.Ranganna, S (1987). 'Hand Book of Analysis and Quality Control for Fruit and Vegetable Products,' New Delhi: Tata McGrawHill Publications.

26.Rao, K.V. \&Gopalan, C (1971).'Family Size and Nutritional Status'. In: Tulpule PG, Jaya Rao KS (eds). 'National Institute of Nutrition Proceedings of the first Asian Congress of Nutrition.

27.Rao, M.B., Prasek, M. \&Metelko, Z. (2002).“Organization of Diabetes Health Care in Indian Rural Areas," DiabetologiaCroatica 31(3) 161-171.

28.Schneider, K., Laube, H. \& Linn, T. (1996). "A Diet Enriched in Protein Accelerates Diabetes Manifestation in NOD Mice," Acta Diabetologica 33(3) 236-240.

29.Shobana, R., Snehalatha, C., Latha, E., Vijay, V. \& Ramachandran, A. (1998) "Dietary Profile of Urban South Indians and Its Relation with Glycaemic Status," Diabetes Research and Clinical Practice 42(3) 181-186.

30.Thakur, G.,Mitra, A., Pal, K. \& Rousseau, D. (2009)."Effect of Flaxseed Gum on Reduction of Blood Glucose \& Cholesterol in Type 2 Diabetic Patients," International Journal of Food Sciences and Nutrition60(s6) 126-136.

Sutapa Mukherjee, BaishakhiDey, Subhayan Das, Goutam Thakur, Chandan Chakraborty and AnalavaMitra(2015), JMED Research, DOI: 10.5171/2015.109848 